Article

\title{
Centering the Complexity of Long-Term Unemployment: Lessons Learned from a Critical Occupational Science Inquiry
}

\author{
Rebecca M. Aldrich ${ }^{1, *(\mathbb{D})}$, Debbie Laliberte Rudman ${ }^{2}{ }^{\mathbb{D}}, \mathrm{Na}$ Eon (Esther) Park ${ }^{1}$ and \\ Suzanne Huot ${ }^{3}$ (D) \\ 1 Chan Division of Occupational Science and Occupational Therapy, University of Southern California, \\ Los Angeles, CA 90008, USA; naeonpar@usc.edu \\ 2 Faculty of Health Sciences, Western University, London, ON N6A 3K7, Canada; drudman@uwo.ca \\ 3 Department of Occupational Science and Occupational Therapy, University of British Columbia, \\ Vancouver, BC V6T 1Z4, Canada; suzanne.huot@ubc.ca \\ * Correspondence: rebecca.aldrich@chan.usc.edu
}

Received: 11 August 2020; Accepted: 7 September 2020; Published: 11 September 2020

\begin{abstract}
Inquiries that rely on temporal framings to demarcate long-term unemployment risk generating partial understandings and grounding unrealistic policy solutions. In contrast, this four-phase two-context study aimed to generate complex understandings of post-recession long-term unemployment in North America. Grounded in a critical occupational perspective, this collaborative ethnographic study also drew on street-level bureaucracy and governmentality perspectives to understand how social policies and discursive constructions shaped people's everyday 'doing' within the arena of long-term unemployment. Across three phases, study methods included interviews with 15 organizational stakeholders who oversaw employment support services; interviews, participant observations, and focus groups with 18 people who provided front-line employment support services; and interviews, participant observations, time diaries, and occupational mapping with 23 people who self-identified as being long-term unemployed. We draw on selected interviews and mapping data to illustrate how participants' definitions and experiences of long-term unemployment reflected and moved beyond dominant temporally based framings. These findings reinforce the need to expand the dominant conceptualizations of long-term unemployment that shape scholarly inquiries and policy responses. Reflections on the benefits and challenges of this study's design also reinforce the need to use multiple, flexible methods to center the complexity of long-term unemployment as it is experienced in everyday life.
\end{abstract}

Keywords: long-term unemployment; critical occupational perspective; methods

\section{Introduction}

During and following the 2008 recession, the increased prevalence and persistence of long-term unemployment [1-4] reignited discussions about the adequacy of dominant economic classifications for informing governmental statistical and policy approaches [1,4-15]. The International Labour Organization [16] defines long-term unemployment as being without formal paid employment for at least one year despite an active job search in the past four weeks. Critical commentary highlights how this definition underestimates long-term unemployment by creating an oversimplified dichotomy, one that demarcates people as in or out of work based on temporal markers and the active nature of job-seeking activities. Such a dichotomy masks 'hidden unemployment' experiences wherein people vacillate between a lack of paid work, underemployment, and cyclical engagement in insecure employment. Inquiries that rely on dichotomous, rigid, or reductionistic definitions and categories of 
long-term unemployment risk failing to capture the scope and complexity of this social problem; in turn, such inquiries can only offer a partial basis for informing policy solutions that aim to address people's experiences with long-term unemployment. By limiting who 'counts' as long-term unemployed, inquiries and policies also risk contributing to the further marginalization of people outside full-time, sustained engagement in the formal labor force.

Within this context of persistent long-term unemployment and debates about the adequacy of temporally based economic classifications, the study described herein aimed to illuminate the complex character and implications of contemporary long-term unemployment in North America. In recognition of the blurred boundaries between unemployment, underemployment, precarious employment, and long-term unemployment, the study aimed to move beyond a basis in dominant temporal classifications. Instead, it generated grounded conceptualizations to illuminate long-term unemployment as "an entire social process related to joblessness" [12] (p. 35) that people navigate and negotiate every day [17]. The study utilized a critical perspective developed within the discipline of occupational science $[18,19]$ to explore how discursive constructions and concrete conditions shaped everyday 'doing' in relation to long-term unemployment. Departing from common understandings of 'occupation' as solely referencing work, the international discipline of occupational science focuses on the range of 'doings' that constitute people's lives and routines, including but not restricted to work (broadly conceived), caregiving, household maintenance, resource management, leisure, and rest. In turn, a critical occupational perspective underscores the influence of expectations about how people ought-and ought not-to engage in occupations based on their intersectional identities [20], social positions, and circumstances, with particular attention to how such expectations are shaped by wider sociopolitical systems and structures [21].

In situations of unemployment specifically, people are subject to explicit and implicit expectations about the ways they should and should not spend their time; these expectations manifest directly in benefit and support systems such as employment/unemployment insurance and job counseling. In many contemporary societies, activity expectations within these systems often derive from a broader neoliberal emphasis on individual responsibility and activation. This neoliberal emphasis prioritizes activities and decisions that enhance marketability and facilitate rapid (re)employment, such as engagement in skill-building workshops, acceptance of precarious employment, and active job-seeking [22-29]. However, compliance with activity expectations does not guarantee escape from the problems associated with long-term unemployment, given labor market changes, persistent forms of discrimination, and other systemic barriers to sustainable employment [30]. Moreover, in line with an occupational perspective, employment-related activities comprise only part of what people need to do to survive and support themselves, their families, and their communities as they navigate everyday life. Thus, this study aimed to center and highlight the complexity and full range of occupational engagements that comprise daily life as a means of more fully illuminating the nature of contemporary long-term unemployment.

This paper presents selected findings to problematize limitations placed on what and who counts and is addressed within services, policies, and inquiries on long-term unemployment. After a brief description of the study's design and methods, the paper presents three sets of findings: participant-generated definitions and descriptions of long-term unemployment; stakeholder and service provider perspectives on how various definitions enter into their work; and participant-generated maps of their lived experiences of long-term unemployment. These findings complement existing ethnographic accounts of unemployment [14], and by demonstrating the connection between grounded conceptualizations and concrete lived realities of long-term unemployment, they extend critiques advanced in sociological and anthropological literature. Our discussion focuses on the need for an expanded conceptualization of long-term unemployment and highlights how methodological choices based on a commitment to centering complexity and everyday occupations illuminated understandings and phenomena that might otherwise have remained invisible. The paper ends with a critical discussion 
of the policy implications and conceptual and methodological challenges associated with investigating the contemporary production and complex experience of long-term unemployment.

\section{Materials and Methods}

\subsection{Theoretical Underpinnings}

To understand how long-term unemployment is shaped, navigated, and negotiated in contemporary North American contexts, this study drew on three theoretical foundations. First, a governmentality perspective [31,32] based on the work of Foucault [33] helped illustrate how particular ways of doing come to be shaped as 'ideal' or 'non-ideal' for particular types of subjects (e.g., active job seeking and self-marketing are idealized for 'the unemployed'), and how technologies of governance circulate idealized subjectivities and practices through discursively framed social policies and service provision processes (e.g., activation-based job counseling services). We drew on a governmentality perspective to deconstruct how the market-ethos and individualism at the center of neoliberal rationality are drawn upon to govern the conduct of the unemployed. In particular, we used this perspective to foreground how neoliberal rationality seeks to activate self-governing entrepreneurial subjects, who are seen as driven to optimize their marketability in alignment with the needs and aims of the labor market [28,34]. Our inquiry focused on the impact of this narrow conceptualization of entrepreneurial beings as mobilized through neoliberal discourses and policy changes, specifically how the individualization of responsibility for the social problem of unemployment obscures socio-political barriers to its resolution [18,34-36]. Second, we drew on the notion of street-level bureaucracy [37], which frames service provision interactions as sites of governance and front-line service providers as people who 'make' policy through their everyday work. This perspective helped us understand how everyday needs for resource seeking [38] to make ends meet during long-term unemployment brought people into direct contact with structures of governance (e.g., front-line service providers), which in turn shaped their broader behavior in alignment with idealized subject positions (e.g., activated job-seeker). Third, we drew on the critical occupational perspective described above to focus on the occupational implications of long-term unemployment vis-a-vis people's complex negotiations of human and non-human influences on everyday life $[30,39,40]$. A critical occupational perspective begins from the assumption that people are occupational beings who need to engage in a variety of occupations-not just work-to survive and thrive as individuals and members of collectives. The critical framing of this perspective uses various critical social theories (such as governmentality, decolonial, and feminist theories, for example) to illustrate how taken-for-granted assumptions and power structures shape access to and engagement in the occupations that constitute life [19,21]. Overall, our combined theoretical foundations in governmentality, street-level bureaucracy, and critical occupational science helped us examine how neoliberal activity expectations, as mobilized through social policies and enacted in street-level bureaucracies, shaped the ways that people thought about and participated in diverse occupations in relation to long-term unemployment. These theoretical foundations also helped us explore tensions that arose when narrow neoliberal conceptualizations of people as entrepreneurial beings failed to acknowledge the full complexity of people's lived experiences as occupational beings.

\subsection{Study Design}

This study utilized a collaborative ethnographic approach [41] in partnership with an international non-profit organization. We generated data in two mid-sized cities-one in the United States and one in Canada-between 2014 and 2016 and engaged in knowledge mobilization activities through mid-2018. Across the first three study phases, methods included interviews with organizational stakeholders who oversaw employment support services; interviews, participant observations, and focus groups with people who provided front-line employment support services; and interviews, participant observations, time diaries [42], and/or occupational mapping [43] with people who self-identified as being long-term unemployed (See Figure 1). 


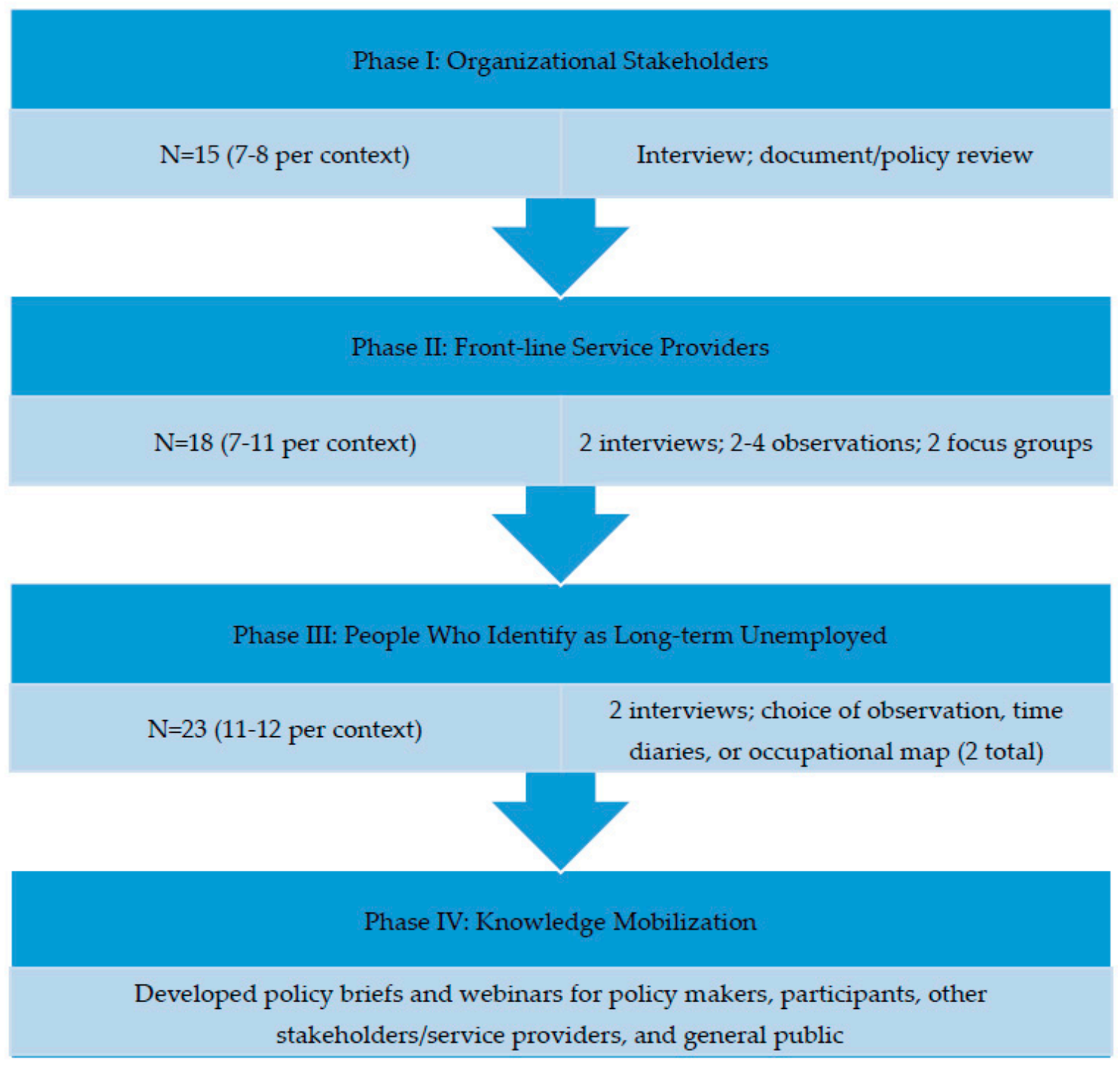

Figure 1. Study design.

\subsection{Participant Recruitment and Demographics}

We purposively recruited participants for phases I and II from agencies that provided employment supports and related services in each study context. We recruited Phase III participants from similar agencies through flyers, presentations, and snowball sampling through word-of-mouth, using an approach that relied on participants' self-identification as long-term unemployed to avoid undue exclusion that might result from the imposition of a standard definition. Table 1 illustrates the agency affiliations and lengths of professional experience for participants in Phases I and II, and Table 2 lists demographic and un/employment information for Phase III participants along with the study methods in which they participated. 
Table 1. Phases I and II participant information.

\begin{tabular}{|c|c|c|c|c|}
\hline Context & Phase & Alias & Organization Type & $\begin{array}{l}\text { Length of Experience in } \\
\text { Arena at Time of Interview }\end{array}$ \\
\hline Canada & I & Michael & Regional business development organization & 18 years \\
\hline Canada & I & Kim & $\begin{array}{l}\text { Provincially funded employment support } \\
\text { and training services }\end{array}$ & 1 year \\
\hline Canada & I & Victoria & Municipal social services & 40 years \\
\hline Canada & I & Alyssa/Lindsey & $\begin{array}{l}\text { Provincial employment support and training } \\
\text { services }\end{array}$ & 28 years/20 years \\
\hline Canada & I & Zack & Provincial ministry of training and education & 10 years \\
\hline Canada & I & Ria & Regional employment advisory board & 12 years \\
\hline Canada & I & Jenna & $\begin{array}{l}\text { Provincially funded employment support } \\
\text { and training services }\end{array}$ & 6 years \\
\hline $\begin{array}{l}\text { United } \\
\text { States }\end{array}$ & I & Charlie & Community college training program & 11 years \\
\hline $\begin{array}{l}\text { United } \\
\text { States }\end{array}$ & I & Nick & Municipal social services & 3 months \\
\hline $\begin{array}{l}\text { United } \\
\text { States }\end{array}$ & I & Brian et al. & $\begin{array}{l}\text { Municipal/State employment support and } \\
\text { training services }\end{array}$ & Varied (group interview) \\
\hline $\begin{array}{l}\text { United } \\
\text { States }\end{array}$ & I & Catherine & $\begin{array}{l}\text { Municipal/State employment support and } \\
\text { training services }\end{array}$ & 15 years \\
\hline $\begin{array}{l}\text { United } \\
\text { States }\end{array}$ & I & Jennifer & $\begin{array}{l}\text { Municipal/State employment support and } \\
\text { training services }\end{array}$ & 7 years \\
\hline $\begin{array}{l}\text { United } \\
\text { States }\end{array}$ & I & Andrea & Regional training and resource center & 11 years \\
\hline $\begin{array}{l}\text { United } \\
\text { States }\end{array}$ & I & Carter & $\begin{array}{l}\text { Municipal/State workforce development } \\
\text { services }\end{array}$ & 10 years \\
\hline $\begin{array}{l}\text { United } \\
\text { States }\end{array}$ & I & Joe & $\begin{array}{l}\text { Non-profit community organization for } \\
\text { immigrants }\end{array}$ & 6 years \\
\hline Canada & II & Emily & $\begin{array}{l}\text { Provincially funded employment support } \\
\text { and training services (community based) }\end{array}$ & 24 years \\
\hline Canada & II & Sarah & $\begin{array}{l}\text { Provincially funded employment support } \\
\text { and training services (community based) }\end{array}$ & 5 years \\
\hline Canada & II & Dwight & $\begin{array}{l}\text { Provincially funded employment support } \\
\text { and training services (community based) }\end{array}$ & 10 years \\
\hline Canada & II & Courtney & $\begin{array}{l}\text { Provincially funded employment support } \\
\text { and training services (connected with local } \\
\text { college) }\end{array}$ & 5 years \\
\hline Canada & II & Hillary & $\begin{array}{l}\text { Provincially funded employment support } \\
\text { and training services (connected with local } \\
\text { college) }\end{array}$ & 3 years \\
\hline Canada & II & Natalie & $\begin{array}{l}\text { Provincially funded employment support } \\
\text { and training services (community based) }\end{array}$ & 3 years \\
\hline Canada & II & Jerry & $\begin{array}{l}\text { Provincially funded employment support } \\
\text { and training services (community based) }\end{array}$ & $\begin{array}{l}\text { Unspecified (observation } \\
\text { session only) }\end{array}$ \\
\hline Canada & II & Kate & $\begin{array}{l}\text { Provincially funded employment support } \\
\text { and training services (community based) }\end{array}$ & 22 years \\
\hline Canada & II & Kevin & $\begin{array}{c}\text { Provincially funded employment support } \\
\text { and training services (connected with local } \\
\text { college) }\end{array}$ & 5 years \\
\hline Canada & II & Nicole & $\begin{array}{l}\text { Provincially funded employment support } \\
\text { and training services (connected with local } \\
\text { college) }\end{array}$ & 15 years \\
\hline Canada & II & Megan & $\begin{array}{l}\text { Provincially funded employment support } \\
\text { and training services (community based) }\end{array}$ & 20 years \\
\hline Canada & II & Teresa & $\begin{array}{l}\text { Provincially funded employment support } \\
\text { and training services (community based) }\end{array}$ & 9 years \\
\hline
\end{tabular}


Table 1. Cont.

\begin{tabular}{|c|c|c|c|c|}
\hline Context & Phase & Alias & Organization Type & $\begin{array}{l}\text { Length of Experience in } \\
\text { Arena at Time of Interview }\end{array}$ \\
\hline $\begin{array}{l}\text { United } \\
\text { States }\end{array}$ & II & Marie & $\begin{array}{l}\text { Non-profit employment services for domestic } \\
\text { violence survivors }\end{array}$ & 5 years \\
\hline $\begin{array}{l}\text { United } \\
\text { States }\end{array}$ & II & Tom & $\begin{array}{l}\text { Non-profit employment services for people } \\
\text { with disabilities }\end{array}$ & 10 months \\
\hline $\begin{array}{l}\text { United } \\
\text { States }\end{array}$ & II & Bree & $\begin{array}{l}\text { Non-profit employment services for cultural } \\
\text { groups }\end{array}$ & 26 years \\
\hline $\begin{array}{l}\text { United } \\
\text { States }\end{array}$ & II & Erin & $\begin{array}{l}\text { Non-profit employment services for } \\
\text { immigrants }\end{array}$ & 1 year \\
\hline $\begin{array}{l}\text { United } \\
\text { States }\end{array}$ & II & Liz & $\begin{array}{l}\text { Municipal/State employment services for } \\
\text { welfare recipients }\end{array}$ & 12 years \\
\hline $\begin{array}{l}\text { United } \\
\text { States }\end{array}$ & II & Taylor & $\begin{array}{l}\text { Non-profit employment services for } \\
\text { immigrants }\end{array}$ & 3 months \\
\hline $\begin{array}{l}\text { United } \\
\text { States }\end{array}$ & II & John & $\begin{array}{l}\text { Non-profit employment services for } \\
\text { community welfare recipients }\end{array}$ & 5 months \\
\hline
\end{tabular}

Table 2. Phase III participant information.

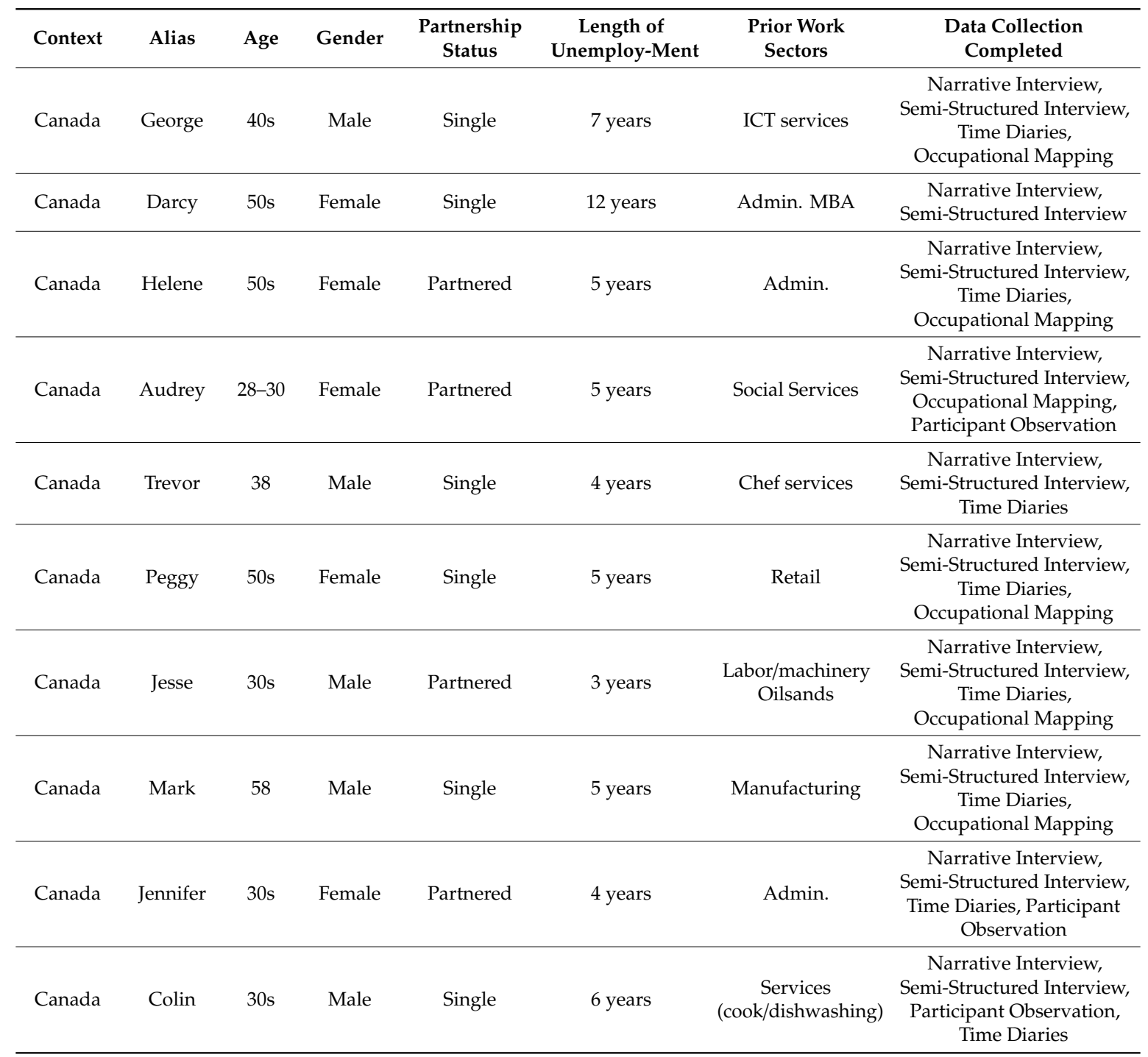


Table 2. Cont.

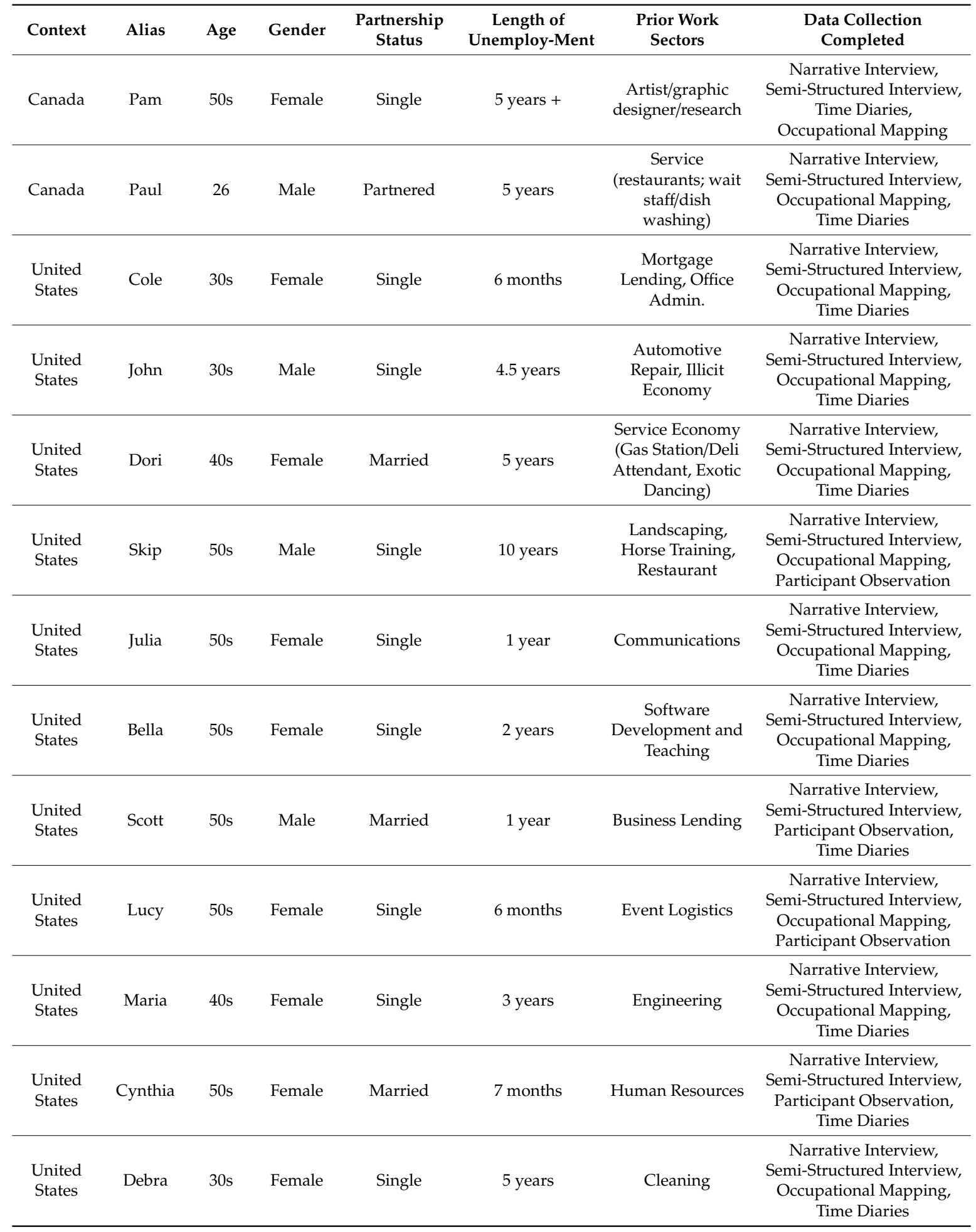

\subsection{Description of Methods}

Within this article, we draw on selected data to elucidate how various types of participants understood and defined long-term unemployment, as well as how elements of those definitions were reflected in Phase III participants' lived experiences of unemployment. Consequently, the following descriptions highlight individual and focus group interview and occupational mapping methods 
without detailing other study methods (e.g., critical discourse analysis of policy documents, participant observation, and time diaries) that were less germane to this article's purpose.

Phase I. We conducted semi-structured interviews with stakeholders who were involved in establishing and delivering employment support services in each context. These interviews helped build a baseline for understanding how employment support services were organized in each study context, how service organizations had been shaped by policy changes since the 2008 recession, and how stakeholders defined long-term unemployment [44].

Phase II. We conducted semi-structured and focus group interviews with people who provided front-line services at support organizations. These interviews aimed to illuminate how participants understood their professional role in relation to the problem of and solutions for long-term unemployment. In particular, we explored how service providers understood and defined long-term unemployment; what types of clients they perceived as 'at risk' for long-term unemployment; and what factors placed such clients 'at risk'. Two focus group conversations-one among service providers within each study context and one that connected service providers across contexts-also provided an opportunity to discuss our emerging understandings and refine them based on Phase II participants' reflections and input.

Phase III. Informed by what we learned in Phases I and II, we conducted individual narrative and semi-structured interviews with people who received employment support services and self-identified as long-term unemployed. In addition to interviews, we asked Phase III participants to choose two data collection methods from a list of possibilities, including participant observation, time diaries, and occupational mapping, to help us more fully understand the complexity of their lived experiences. This choice of methods reflected our commitment to the power-sharing intentions underlying collaborative ethnography [41], as well as our recognition that participants would have different preferences for representing their experiences. One of these methodological options, the occupational mapping method [43] involved having participants visually represent the places they went in their daily lives. While drawing on a piece of paper, participants verbally described where they went, how they got there, why they went there, and what they did at each place. We audio-recorded those descriptions and transcribed them for later review alongside the participant-generated maps.

See Appendix A for a list of Phase I, II, and III interview questions designed to elicit participants' definitions of long-term unemployment.

\subsection{Analytic Approaches}

For interview and focus group data, our recursive analytic process combined governmentality theory-informed critical discourse analysis with inductive approaches [45] to identify main lines of meaning expressed in relation to the definition and negotiation of long-term unemployment. We used Quirkos qualitative analysis software to systematically code interview and focus group data via descriptive, in vivo, and theoretically informed coding approaches. We generated initial descriptive codes using themes from previous pilot research $[30,39]$ and derived theoretical codes from our theoretical lens. We expanded and collapsed codes through the iterative coding process. For occupational mapping data, we identified a list of places and occupations that participants represented on the maps and developed a series of open-ended analytic questions informed by our theoretical lens to facilitate reflexive and interpretive analysis of maps and corresponding transcripts (see [46] for further details). Our analysis began with a pre-defined list of 12 types of places and nine occupational categories based on understandings developed through previous pilot research [30,39] and information obtained in narrative and semi-structured interviews with each participant. As our iterative analysis of the 17 maps progressed, our list expanded to include 32 categories of places and 21 categories of occupation. Once we coded the visual data, each researcher used the reflexive guide to identify key elements of each map, which facilitated later comparisons across participants and study contexts. In this paper, we integrate four participants' maps to illustrate the heterogeneity of everyday experiences across similar durations of unemployment in the United States and Canada. We highlight 
two female participants from each study context, all of whom reported being unemployed for five years. This duration of unemployment was most frequently reported across participants $(n=8)$.

\subsection{Ethical Permissions}

All study elements (design, methods, and analytic approaches) were granted university ethics board approval in the respective study contexts. We utilize aliases throughout the presentation of the findings below.

\section{Findings}

We begin by sharing findings from semi-structured individual and focus group interviews in which we asked participants about their definitions of long-term unemployment. In responding to our questions, participants across Phases I, II, and III provided definitions that highlighted temporal, labor force, financial, and emotional aspects of long-term unemployment. Some program managers and service providers also suggested that people who experience long-term unemployment should be the ones defining the phenomenon, recognizing that it is situated in the complex interaction of the aforementioned aspects. These data disrupt dominant approaches to defining long-term unemployment, pointing instead to the need for definitions that account for a variety of complex relationships.

After illustrating aspects of participants' definitions, we present other semi-structured individual and focus group interview data that address how front-line service providers incorporated varied definitions of long-term unemployment into their work. These findings address how service providers negotiated differences between the official definitions of long-term unemployment that shaped their professional work and the grounded and material aspects that defined their clients' lives. These findings illustrate the limited utility of temporally based definitions for the day-to-day work of front-line service provision, as well as the restrictions that such definitions can place on clients' broader service eligibility.

Finally, we present selected occupational mapping data to illustrate the shape of everyday life for participants who identified as long-term unemployed. The occupational mapping data show how dimensions of precarity and emotional changes intersected in participants' lives. The visual representations of this intersection via the occupational maps provide a way to understand how similar durations of long-term unemployment can be heterogeneous in important ways. These findings reinforce the complexity and variability that participants' on-the-ground definitions of long-term unemployment aimed to illuminate.

\subsection{Aspects of Participant Definitions}

\subsubsection{Duration of Unemployment}

Duration of time outside paid work is the primary feature of official unemployment definitions, and many participants across study phases used temporal markers in their own definitions of long-term unemployment. However, participants framed these temporal markers as variable and as needing to be considered in light of other contextual aspects through which the absence of employment occurred.

Among program managers and service providers, stated temporal markers ranged from two weeks to several years, indicating that what makes a particular unemployment experience 'long-term' is much more variable than what official definitions stipulate. For example, Charlie, a program manager in the United States, said,

I think that when we deal with the state on some of our programs, when they talk about long-term unemployment they talk about people who have exhausted their 26 weeks of eligibility of unemployment compensation which is now going down to 21 weeks or something... But I think that when we talk about long-term unemployed just around here, when you talk about it, not in the context of specific eligibility requirements of a specific program, I think we're talking about folks that were never more than marginally attached to the labor force... So there's sort of a technical definition, which we have to adhere to in many cases, and then there's the longer. 
Similarly, Steve, a program manager in the United States stated, "the definition from my understanding in [this state] is anything over 20 weeks. Federal government is 27 weeks ... if you're looking at providers, they're talking about that cyclical job after job after job over a period of just like you said, multiple years." Kevin, a Canadian service provider, added a more action-based element to his temporal definition, describing clients as long-term unemployed when they "are doing everything right. They are sending their resumes and interviews ... [for] 6 months to a year."

Rather than referring directly to official temporal markers and seeking to redefine or expand them, participants who self-identified as being long-term unemployed referenced both the duration of their job-seeking activities and the impact of that duration on their sense of possibility for employment and broader life. Skip, who had a varied work history in restaurant and landscaping industries in the United States, said, " ... when a couple of months go by, then it's pretty well given that there's not, you know, going to be much happening." Trevor, a former employee in the Canadian foodservice industry, said, "my idea of long-term unemployment was like a month, certainly not a year, and a-well, we're going on almost three, almost four years now." He defined long-term unemployment as occurring "when your employment situation starts negatively affecting your life. Not necessarily the lifestyle-I don't need a whole lot of stuff, but when it affects my ability to provide for my kids, provide basic needs for myself." Helene, who had a professional background as a case manager in Canada, said that long-term unemployment occurred between six months and one year in duration when "it's getting pretty desperate" and "it was just sort of constant not getting calls for interviews ... it was a process." Mark, who had a history of working in the Canadian manufacturing sector, simply said that "any period of time where you get used to being unemployed" constitutes a 'long-term' situation.

\subsubsection{Patterns of Labor Force Participation}

Building on the above examples, participants often referenced cyclic unemployment, underemployment, precarious employment, and chronic unemployment in response to questions about how they defined and experienced long-term unemployment. These responses reflected an on-the-ground blurring of labor market distinctions, challenging characterizations that long-term unemployment ends whenever employment of any quality or sustainability is obtained.

Sarah, an employment counselor from Canada, gave the following example: "I have one individual client, this year alone I have closed and opened [their file] four separate times... even though they're working, that's being unemployed. There's no gainful employment. There's no change to their circumstance." Similarly, Marie, a service provider in the United States, described "this chronic pattern of getting positions and losing them .... even if they get a job and keep it for a few weeks or a couple months... it's not sustaining them, their livelihood long-term." Participants who identified as long-term unemployed noted a similar blurring between full-time sustaining work and movements in and out of the labor force. Bella, a former teacher in the United States, described her long-term unemployment as the result of multiple firings and hirings: "when I first was unemployed-I actually got employed a couple months after that, but-you know, I kept getting laid off." Likewise, George, a former information technology worker in Canada, challenged the notion that any engagement in paid work resolved long-term unemployment, stating that "working four hours in a two-week period is definitely not working-it's just doing something during that time."

\subsubsection{Financial Precarity}

Across study phases, participants touched on financial precarity as a defining element of long-term unemployment. Specifically, participants highlighted issues of access to, type, and adequacy of financial assistance and resources as determinants of unemployment being experienced as 'long-term'.

In Canada, Michael, a workforce program director, said, "long-term unemployment comes at a point where you have no form of ... financial assistance" such as severance pay, unemployment insurance, or other income replacements. Jesse, who came from an industrial job background in Canada, defined his long-term unemployment as happening when he had no choice but to apply 
"for [welfare], which I never thought I'd have to in my life, that's when I knew." Moving away from a focus on government-funded financial assistance, Diane, a program manager from the United States, spoke more broadly about individual financial resources, stating:

I know what we say long-term unemployed is but to the job seeker it would be anytime you can't pay your bills, when you start losing your home and your cars, can't put food on your table, can't pay your utility bills. So that could be anywhere from three weeks or six weeks for some people.

Dwight, an employment counselor in Canada, used a metaphor to describe the financial precarity that often accompanies long-term unemployment: “...it's walking the edge of the cliff for several months at a time. You simply don't have an ability to create a platform to stand on, so you're rushing to the next small piece." Likewise, Bree, a service provider in the United States, said that

[Long-term unemployment] depends really upon the situation of the individual client, especially upon that client's financial situation. For some people, missing one or two paychecks can be catastrophic. For others, they're content to wait until 'the ideal job' comes along.

Dori, who had previously held a range of service economy jobs in the United States, shared similar ideas based on her current unemployment experience:

Long-term unemployment to me would be anything over a month. I look at it as anything that can put you in a position to where you're possibly not going to be able to dig yourself out. You're gonna have to go through some super hard times before you can get back to where you were. I would say a month, month and a half because that gives you enough time if you live paycheck to paycheck to kind of go, 'Okay, well, now I haven't been able to pay this bill.'

Maria, who had been an engineer in the United States, described long-term unemployment as "digging into your savings, running low. And then you start digging into $401 \mathrm{~K}$ [retirement plan holdings] and just ... you're getting lower and lower."

Interestingly, even participants who were not currently experiencing financial precarity acknowledged it as a salient element of long-term unemployment. Lucy, who had previously worked in student development in the United States, said,

I would think being out of work with your resources becoming a concern, with your energy-I don't know if that's the right word-I'm just looking at my colleagues and some of them are getting discouraged and things like that. I'm not at that point.

Lucy's definition of long-term unemployment was thus based not only on her own situation-which she described as momentarily stable due to her "frugal" nature-but also on the potential of what her situation could become, in part based on what she saw happening in other people's lives. Scott, a former executive in the United States agricultural sector, was not in a financially precarious situation, but he was beginning to see a future in which he would have to make difficult financial choices if he was unable to find employment:

I had saved a decent amount of money so we're lucky enough to have that to fall back on, but again, as someone who saved a lot of money with the anticipation of using it for retirement, it's not something I want to do.

Thus, even for participants with more financial resources, the potential for eventual financial precarity shaped their definitions of long-term unemployment. Several of these participants also described how their decisions to ensure their current stability-often by relying on savings or withdrawing pension or retirement funds early-risked creating a more precarious future if they were unable to recoup those financial losses through future employment. 


\title{
3.1.4. Emotional Changes
}

Many participants spoke about emotional changes as a marker of a transition from being unemployed to considering oneself long-term unemployed. Dwight, a Canadian employment counselor, described seeing "this cycle of precarious long-term unemployment where the client begins to feel somewhat dejected. They turn into a little bit of Eeyore [a pessimistic character from the children's book series Winnie the Pooh], 'Oh, well, here we go again, got to job seek again.' And it becomes very routine." This description mirrored Cole's experience as a job seeker in the United States after "six months into being unemployed, you kind of lose the momentum that you gain for looking for jobs or even just other opportunities." Similarly, Audrey, who was hoping to find employment as a caseworker in Canada, defined long-term unemployment as

\begin{abstract}
Someone who's struggling ... like you get so discouraged that you're just at a point where, why should I try, you know? Like it's, why am I going to keep sending our resumes, for what, to waste paper? Like, I'm costing myself more money than anything. Like I'm at a point where I'm better off to sit at home on welfare now than to do anything which is sad.
\end{abstract}

These sentiments reflected situations wherein people continued to seek employment despite feelings of discouragement, thus maintaining their distinction from alternative measures of labor underutilization that are commonly used to capture this phenomenon, such as the category of 'discouraged' workers.

Several participants also directly referenced emotional changes associated with the combination of job search failures and financial precarity, such as Maria's comment from the United States that "the definition of [long-term unemployment] is you becoming depressed. You becoming-you feel helpless. It's just the whole consuming-and plus there is fear for future [and] for the present, if you have a family to feed and all these things." John, a service provider in the United States, grouped all of the above elements together in his definition, describing as long-term unemployed

People that fell out of the job market that has pretty much exhausted a lot of their resources, possibly people that have not redefined themselves or retooled themselves, or people that probably, I would say, just gave up on employment for a while, and probably hoping that the market gets better.

\subsubsection{Up to the Individual}

For some program managers and service providers, there were no fixed markers of long-term unemployment; the amalgamation of the above elements prompted people like Kim, a program manager in Canada, to state, "I don't have a definition for that, but ... I just know it when I see it." Jenna, another program manager in Canada, more bluntly stated, "Wow. Long-term unemployment is defined by the individual's perspective, not mine. I know that's a loosey-goosey answer but that's a good career practitioner's answer." Catherine, a program manager in the United States, pointed her definition to the variable ways in which unemployment impacts people, stating: "for instance, if I was unemployed, two weeks would be long-term unemployed for me because I would be at the panic stage at two weeks ... so it's very individualized but I really think it's the need of the job seeker that defines the long-term unemployment." Similarly, Ria, another program manager in Canada, stated, "if there's a certain amount of time, I would say that would be self-defined ... I have no idea how long is too long to be unemployed ... I suspect when a person says, 'Enough is enough' that's probably the cutoff point." Tom, a service provider in the United States, agreed, saying,

It depends on each individual client ... Long-term is kind of up to the individual, but I think it depends on their background, and their values, and their experience-what they consider long-term, versus us. For me, it might be 6 months, but I've had several clients who have had years of unemployment.

Dwight, a service provider in Canada, elaborated on this idea, stating, 
The effects of long-term unemployment in terms of an economic or social status or in terms of just feeling like a person, they vary from individual to individual. So it's hard to define. It's hard to have an empirical answer or a static answer to that because it's so fluid.

\subsection{Definitional Variations and Service Provision}

The above findings illustrate the multifaceted, situated, and dynamic nature of long-term unemployment as experienced by people who are jobless as well as professionals who provide employment support services. The next set of findings, based on interview and focus group data from Phases I and II of the study, illustrate how both front-line service providers and stakeholders negotiated various definitions in their work. Overall, front-line service providers and stakeholders expressed varied perspectives about the impact of official unemployment definitions on their work. Their comments suggested that official definitions based solely on temporal markers did not fully define the scope of their work, however, their acknowledgment of official definitions demonstrates that their work required negotiation of temporally based framings. Many comments from front-line service providers and stakeholders highlighted the contrast of temporally based framings with the more dynamic, fluid, and multifaceted nature of their clients' experiences.

Program managers and front-line service providers expressed varied views about the significance of official definitions of long-term unemployment for their work. For example, Brian, an organizational stakeholder in the United States described how different "funding buckets" — both governmental and non-governmental-restricted service eligibility to clients who matched official definitions: "The funding bucket dictates, well, you got to be out 20 something weeks ... you could ... be five weeks and you walk in the door ... we have to operate. We know what reality is but the policy puts us in a bucket." The diversity of organizational affiliations for Phase I and II participants meant that service provision processes operated with more or less flexibility in relation to funding eligibility requirements. However, the notion that service provision operated in relation to official definitions was something expressed by most stakeholders and service providers. For example, Charlie, another program manager in the United States, further noted the challenge of fitting clients' situations and needs to the official definitions that were used to determine service eligibility:

To me, the most confusing part of this is how to differentiate between long-term unemployed, as in those folks who were at some point in time had a strong attachment to the labor market and then lost that attachment, versus those people that never had it ... the folks that lack any kind of economical opportunity... not all of those meet the eligibility definitions of the Department of Labor or some of the other funding agencies for that matter.

In contrast, other Phase I and II participants stated that official definitions were part of the service provision landscape but did not limit their service provision. Katie, a program manager in the United States said, "we meet folks where they are ... we assess them and then we help them plan out how they want to get where they want to go. So it doesn't matter that you have been out 20 weeks, been out for a day." Likewise, Nicole, a manager in Canada, said

[We] have a very client-centric model whereby the individual is in the driver's seat, and we're coaches and facilitators in helping them to document and then initiate their plan. So how long-term unemployment is defined, I don't think it [impacts] service delivery because every single person is a unique employment action plan depending on a myriad of factors.

Tom, a service provider in the United States, agreed that "whether the definition is considered long-term or short-term is irrelevant. I'm still going to provide the same services, probably about the same level of services, and treat them the same because the objective is to become employed." Marie, also a service provider in the United States, explained that 
A lot of service programs don't advertise 'This is for ... long-term unemployed individuals.' So if someone needs help with a job, they're just going to that agency or being referred in. So I don't think it makes that big of a difference in terms of the service delivery portion of it.

A reliance on client centeredness as a way to resolve the definitional conflict was evident across Phase I and II participants. Both Katie and Nicole framed their work in relation to clients' needs and complex circumstances regardless of the duration of unemployment. Likewise, Tom and Marie's comments suggested that temporally based definitions had little actual utility for the work they did when interacting with clients, even though such definitions impacted which clients might be directed to them in the first place. As street-level bureaucrats [37], these participants used their discretion to determine how-or whether-they took up official temporally based definitions of long-term unemployment to guide their work with clients.

Beyond their use of discretion, however, front-line service providers were also subject to performance management pressures that relied on a dichotomous definition of clients as either being unemployed or in education, training, or work [44,47]. These pressures were expressed primarily by Phase II participants from Canada, who spoke about tensions they experienced between doing what they thought was best for their clients and needing to "tick the box" for a positive client outcome within a specified time frame. This pressure to "make the numbers work" was based on a dichotomous view of clients as either 'employed' or 'unemployed', ignoring the variations and complexities that differentially shaped clients' experiences.

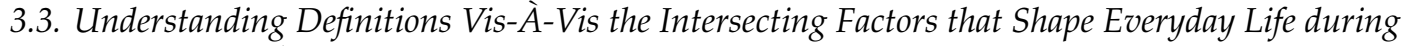 Long-Term Unemployment}

Since service providers recognized the importance of clients' definitions and experiences of long-term unemployment, we end with findings from one additional data source-occupational maps-to illustrate participants' lived experiences of long-term unemployment. We present the maps as drawn by each participant, with particular location names redacted as needed to maintain confidentiality. We present written descriptions along with the maps to describe the everyday situations that each participant navigated; these descriptions reflect information obtained through narrative, semi-structured, and mapping interviews in Phase III of the study.

An initial analysis of four other participants' occupational maps highlighted the intersection of precarity and mobility in lived experiences of long-term unemployment [46]. Specifically, this initial analysis illustrated the salience of participants' experience of financial precarity, which shaped participants' mobilities in their communities and provided a window into the impacts of long-term unemployment on their daily lives. This initial analysis pushed us to analyze the current set of maps in relation to the definitions that participants' generated through the study's interview methods. Thus, this section of findings links back to participants' self-generated definitions and descriptions of long-term unemployment, highlighting that the impact of unemployment on everyday life-not necessarily the duration of unemployment or labor force participation alone-was what participants framed as most relevant for considering what made their unemployment 'long-term.' Collectively, these examples illustrate that grouping people together based on duration of unemployment alone would mask important variations in their respective experiences.

\section{Occupational Maps}

In Canada, Audrey, who was in her late 20s and lived with her two young children, knew she was facing long-term unemployment when she "sent out 557 resumes and didn't get one phone call ... like that was my point of when my hope got sucked out of me." Audrey was struggling to emerge from the cycle of poverty in which she had spent much of her life, and her partner faced his own struggles with unemployment and work-related disability. This idea of struggling-both financially and emotionally-was central to Audrey's definition and experience of long-term unemployment because her successful completion of a caseworker diploma program and countless skill-building workshops 
had so far failed to help her obtain sustainable employment. Audrey had moved to a more rural area with the expectation that it would lower her family's cost of living; however, because she resided rurally, Audrey received less welfare assistance than people who lived in the nearby city, and she was forced to rely on her personal vehicle for transportation to meet her family's needs. Audrey spent lots of time traveling around the region to access needed services (see Figure 2 for details). Her map included five different cities and towns that she interconnected through a series of color-coded arrows, indicating her daily travels (red lines) and job search activities (blue lines). In fact, rather than identifying activities within the town in which she lived, Audrey simply drew a box to represent her home town, reflecting her description of the town as lacking in many basic resources, such as grocery stores. In addition to traveling twice a day to the nearby city to bring her children to and from school, Audrey also traveled to the city to do grocery shopping, participate in a support group for people living in poverty, meet with a welfare program financial worker, and attend medical and dentist appointments as needed. Beyond this near-daily commute to and from the city, Audrey regularly visited three other towns to attend various appointments related to employment counseling and welfare benefits. Her map was dominated by those appointments, and it also had a strong focus on her travel to and from her children's school, as well as the library and splash pad. Despite traveling to a number of different municipalities, Audrey reported doing very few things in any given location. Her map essentially revolved around places related to job seeking, obtaining welfare benefits, grocery shopping, medical appointments, and parenting.

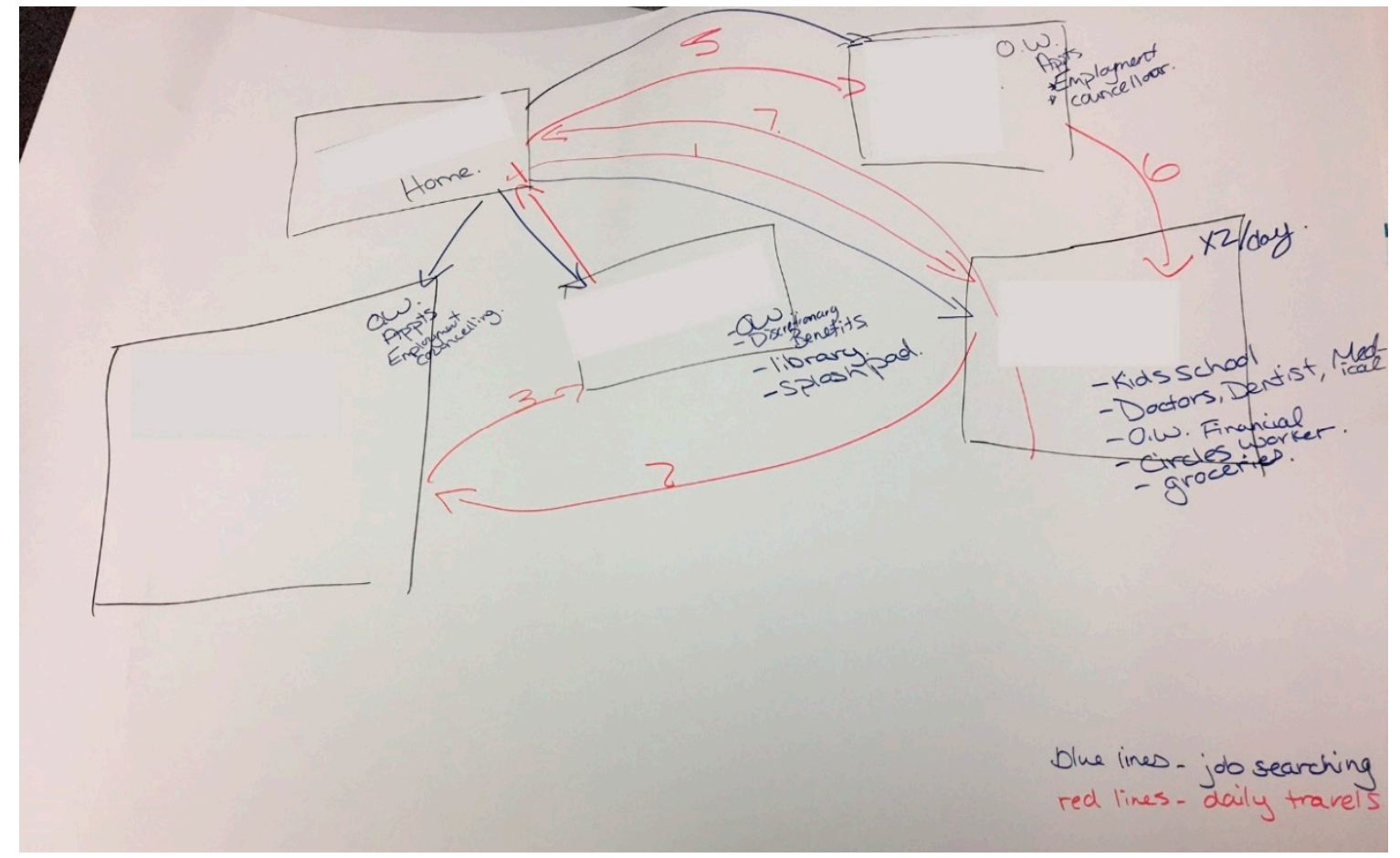

Figure 2. Audrey's map.

In the United States, Debra, who was in her late 30s and resided alone, defined her unemployment as long-term because of the repeated health-related challenges she had faced in retaining a job. She stated, "I've been a diabetic for 19 years so I felt like, at one point I believed that maybe I'm not going to be able to take on a full-time job because of my health issues and I've tried before and I failed." Although she had been working fairly consistently since graduating from high school, she reported that her health conditions "were always getting in the way" of her ability to remain employed for more than a year at a time. Debra did not "have any skills to work in an office or anything like that", so she found it challenging to present herself as a viable candidate for jobs that met her physical needs in light of her 
health conditions. Debra noted that "It's depressing and I don't want to live my life that way and I believe God, that a higher power in me is wanting me to do better. I got to do better. I cannot allow my illness to keep holding me down. That's not an excuse." Like Audrey, Debra had been living in a cycle of poverty since childhood, and she had experienced homelessness before moving into transitional housing with the help of a local organization. Debra resided in a city and primarily utilized the bus for transportation. As shown in her map (see Figure 3 for details), Debra spent much of her time seeking resources and searching for employment. She commented, "I [am] searching. I walk the streets of downtown going to the library. I look for advertisements at [the grocery store]. I [will] be looking for job openings. I go to the library and check the Internet, Craigslist, all that kind of stuff. So yeah I [am] busy trying to seek and then if I'm not seeking that I'm looking for work and I get me some groceries, some canned goods, clothing, and if [not] that I go to [a non-profit organization], I attend their meditation classes and stuff that they have." Her map included no locations for leisure activities and the only retail locations related to securing basic necessities such as food and medications.

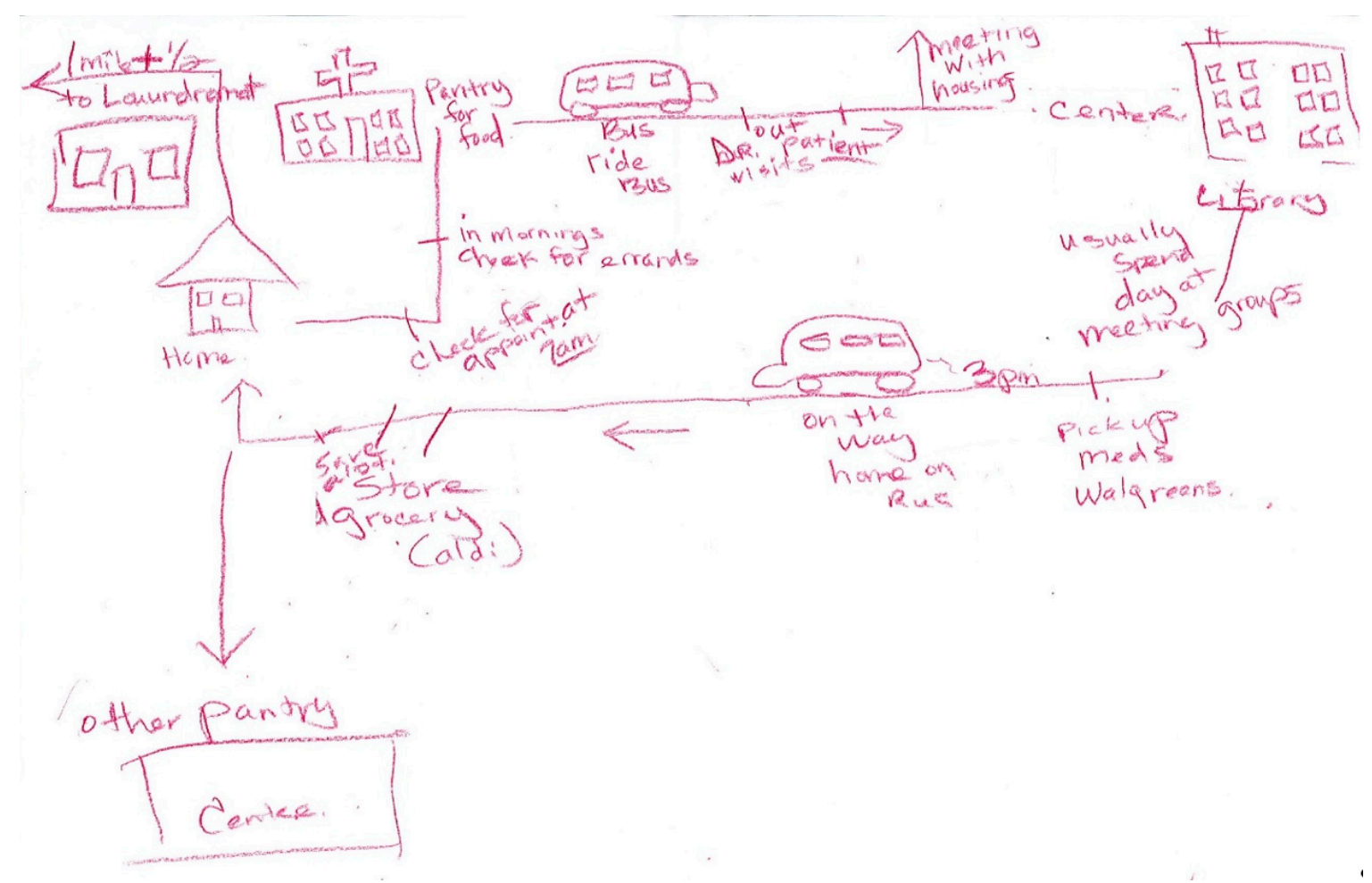

Figure 3. Debra's map.

Dori, who was in her 40s and lived with her husband and teenage son in the United States, came to see herself as long-term unemployed after three months of "serious looking" and "watching people around me get the employment that I thought that I would get." Dori's family was facing imminent eviction because she and her husband, who had also been unemployed for the past three months, owed thousands of dollars in back rent. This personal experience likely shaped Dori's definition of long-term unemployment as "anything over a month. I look at it as anything that can put you in a position to where you're possibly not going to be able to dig yourself out." Dori described herself as "always the kind that worked 2-3 jobs" and she had also spent a number of years as a caretaker for family members, resulting in substantial gaps in her formal employment history. She also described having been "on and off" food stamps for most of her life and she was awaiting notification regarding her application for Temporary Assistance for Needy Families. As she explained while drawing her map (see Figure 4), Dori tried to wade through feelings of hopelessness by sticking to a regular daily routine: "I take [my son to school] ... and then I kinda clean the house up a little bit, jump in the 
shower, go over jobs on Craigslist, and then on Facebook-they've got some really good ones that they, anybody that sees a job, they put it on there-and if there's any that fit for me then I'll fill those out. And then we just go chase in the food pantries like, 'Oh, who's for today? Who's for this?' And then usually, I'm done with all that by like 2:00 and just hope and wait for callbacks ... It's just constantly stressing and looking and hustling trying to find a job and things to figure out what we're gonna do to be able to eat and put food on the table for our kid and it's exhausting." Her map foregrounded her roles as a mother and household caretaker, highlighting destinations she took her son and the various neighborhood resources she accessed to keep her family afloat. Dori did not travel more than a few blocks in any direction from her home, with her furthest destinations located about a mile away; she described this travel radius as an intentional decision to conserve her family's fuel resources.

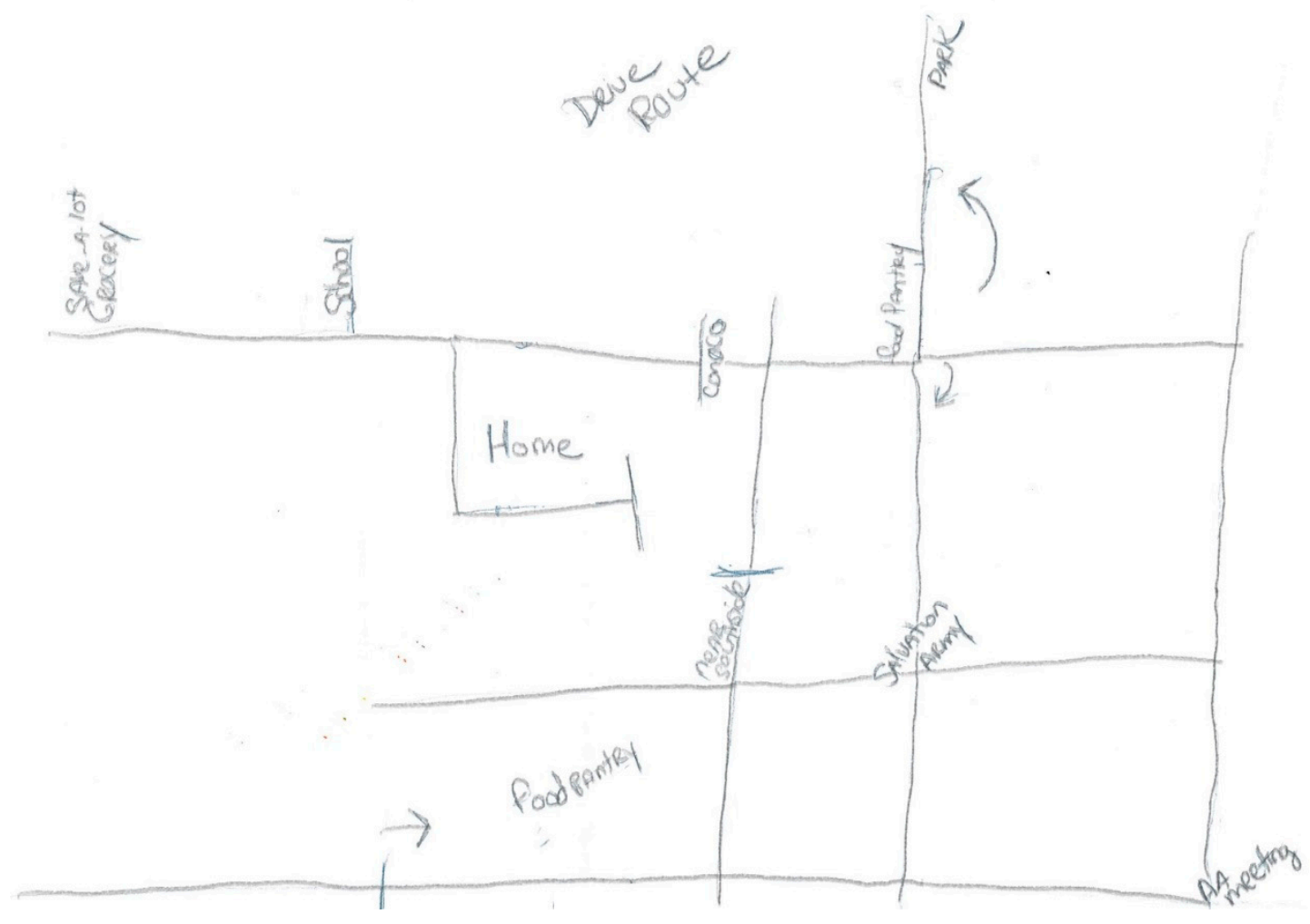

Figure 4. Dori's map.

Finally, Helene, who was in her late 50s and lived with her partner in Canada, reported that she came to see herself as long-term unemployed sometime between six months and one year into her unemployment, after "realizing this is a long process and not short-term because all my life up until then it was always pretty easy to get a job." She received welfare assistance and her partner received an old-age pension, but they still struggled to make ends meet. She kept busy with volunteering and regularly babysitting her three grandchildren. Although Helene generally displayed good humor during her study interviews, she also conveyed marked frustration and described living with constant anxiety and disappointment due to her situation. She spoke at length about the impact of her age and visible physical frailty on her attempts to obtain employment. As her map illustrates (see Figure 5 for details), Helene relied on public transit and this reliance limited where she could seek work and attend various training. Most of her descriptions of her daily occupations centered on the limitations she experienced in relation to them, such as the time it took to travel via public transit, the lack of accessibility on public transit and at certain community destinations, and her lack of discretionary funds to do things with her grandchildren. Although her map did not list as many resource seeking 
sites as Dori and Debra's maps, Helene's overall descriptions of her activities and planning trips by geographical location indicated her persistent need to conserve her minimal resources.

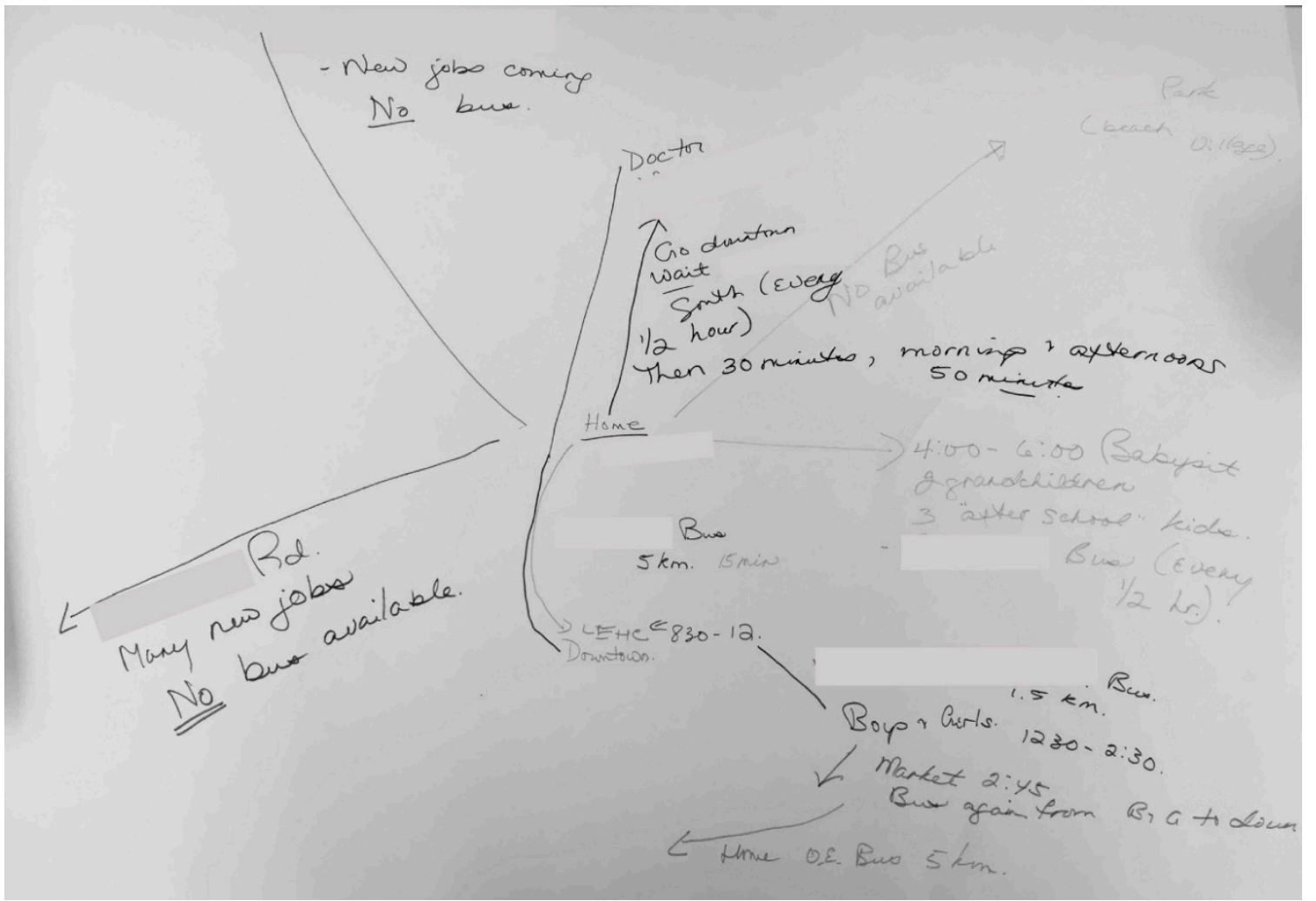

Figure 5. Helene's map.

\section{Discussion and Conclusions}

Taken together, these interview and mapping findings illustrate the complexity of long-term unemployment, both as it is experienced by people who are out of work and as it is framed and approached by people who provide supportive services to jobless individuals. The definitions and illustrations of daily life generated through this study show that similar durations of unemployment can be markedly diverse, even given shared concerns about financial precarity and associated emotional changes. Countering the neoliberal individualizing of unemployment, our findings illustrate that intersecting contextual and personal conditions, such as age, being a parent, transportation options, health of self and loved ones, social benefits, and other factors, shape how individuals experience and understand their situation as one of long-term unemployment. Although demarcating 'unemployment' from 'long-term unemployment' implies a temporal element, based on these findings, we question the salience of temporal duration as the sole marker of long-term unemployment because it unduly limits what and who 'counts' and is addressed within services, policies, and inquiries. Any one-size-fits-all approach that sets boundaries on long-term unemployment based on temporal duration alone excludes the varied aspects that constitute lived experiences, thus inevitably failing to support diverse needs for many people.

In a neoliberal landscape, a key function of official definitions is to narrow the number of people eligible for services and supports to align with broader austerity goals [5,36,48]. Neoliberal framings of long-term unemployment that use temporal definitions to determine who is included and excluded from statistics and supportive services gloss over complexity and variation in an attempt to homogenize and individualize the problem. We intentionally designed our study so that it would build on participants' own definitions of long-term unemployment and center the complexity of their 
experiences as conveyed through a focus on their occupations. Our analysis aimed to contextualize participants' definitions within actual lived experiences and wider national and sociopolitical contexts. In making choices to privilege the complexity and nuance of long-term unemployment, we were able to illuminate understandings about the shaping of everyday life that might have remained invisible if we assumed that long-term unemployment was demarcated by temporal duration alone. In particular, our findings show how individualized activation approaches rooted in the notion of people as entrepreneurial beings are limited in their ability to resolve long-term unemployment, given the varying intersections of personal and contextual influences that shape this phenomenon.

One advantage of using a critical occupational perspective is that it linked participants' current doing to their future becoming as occupational beings $[49,50]$. This perspective helped reveal that long-term unemployment is not just about the 'now' that is reflected in temporally based definitions, but also about the future, particularly in relation to precarity that might be both increasing and unending. We see this effort to center the complexity of long-term unemployment through multiple and diverse occupation-focused methodological approaches as essential to charting future policy directions. As our findings show, temporally based definitions of long-term unemployment are abstracted from the conditions of everyday life and hold limited utility for people who are directly implicated in the arena of unemployment. These findings demonstrate the need for broader system changes, such as the creation of more nuanced definitions that facilitate more flexible eligibility criteria, greater access to supportive services, and income support systems that create a stable base for shifting beyond persistent precarity. Future attempts to refine the definition of long-term unemployment will be best served by starting from the lived experiences that related social policies aim to support.

In making this assertion, we recognize the limitations that accompany our study. In basing our recruitment on participant-generated definitions of long-term unemployment and Phase III participants' own self-identification as 'long-term unemployed', we limited our abilities to make comparisons based on shared demographic characteristics. In our effort to support Phase III study participants' choice of methods, we also limited our collection of uniform data across participants. Likewise, the flexibility of the mapping method we used in Phase III yielded participant maps that did not always elicit the same kinds of data, making direct comparisons challenging. Despite the limitations that accompany these study design and methodological choices, we believe they are far outweighed by the study's ability to be faithful to its collaborative ethnographic intent, which calls for researchers to continually invite participants (as consultants) to share their expertise in ways that shape research questions and processes.

In summary, our findings illustrate that temporal markers do not fully encapsulate the experience of long-term unemployment or provide useful guidance for how the problem of long-term unemployment might be resolved. Rather than focusing on the duration of unemployment, people's patterns of labor force participation, or broader dichotomous notions of people being 'in' or 'out' of work, solutions based on people's abilities to make ends meet, engage in everyday life, and generate a sense of possibility for the future provide more fruitful grounds for ameliorating the impacts of long-term unemployment.

Author Contributions: Conceptualization, R.M.A. and D.L.R.; methodology and analysis, R.M.A., D.L.R. and S.H.; investigation, R.M.A. and D.L.R.; project administration: D.L.R. and R.M.A.; data curation, R.M.A. and N.E.P.; writing-original draft preparation, R.M.A.; writing-review \& editing, R.M.A., D.L.R., N.E.P. and S.H.; funding acquisition, D.L.R., R.M.A. and S.H. All authors have read and agreed to the published version of the manuscript.

Funding: This research was funded by the Social Sciences and Humanities Research Council, Insight Grant number 435-2014-0847.

Acknowledgments: We appreciate the contributions of participants across all phases of this study, as well as the many team members (co-investigators, post-doctoral fellows, trainees, and research assistants) who participated in various stages of this project. We are grateful to Kasey Wagstaffe for her assistance with an earlier version of this manuscript.

Conflicts of Interest: The authors declare no conflict of interest. The funder had no role in the design of the study; in the collection, analyses, or interpretation of data; in the writing of the manuscript, or in the decision to publish the results. 


\section{Appendix A}

Table A1. Interview Questions for Eliciting Definitions of Long-term Unemployment.

\begin{tabular}{|c|c|c|}
\hline Phase & Participant Type & Interview Question(s) \\
\hline I & Organizational stakeholders & From your perspective, how do you define long-term unemployment? \\
\hline II & Front-line service provider & $\begin{array}{c}\text { Based on your experiences, how do you define } \\
\text { long-term unemployment? } \\
\text { Reflecting on your experiences, what are the factors that seem to lead } \\
\text { particular clients to experience long-term unemployment? } \\
\text { When in the process of working with a client, do you tend to identify } \\
\text { or know that the person is likely going to be facing } \\
\text { long-term unemployment? }\end{array}$ \\
\hline III & Long-term unemployed people & $\begin{array}{l}\text { At what point did you come to see yourself as experiencing } \\
\text { long-term unemployment? } \\
\text { Was there a particular event or experience that made you think of } \\
\text { your unemployment as long-term? } \\
\text { How do you define long-term unemployment? }\end{array}$ \\
\hline
\end{tabular}

\section{References}

1. $\quad$ Burtless, G. Long-Term Unemployment: Anatomy of the Scourge; Brookings: Washington, DC, USA, 27 July 2012. Available online: https://www.brookings.edu/articles/long-term-unemployment-anatomy-of-the-scourge/ (accessed on 29 July 2020).

2. Hornstein, A.; Lubik, T. The rise in long-term unemployment: Potential causes and implications. Econ. Q. 2016, 101, 125-149. [CrossRef]

3. Kosanovich, K.; Sherman, E.T. Spotlight on Statistics: Trends in Long-Term Unemployment; U.S. Bureau of Labor Statistics: Washington, DC, USA, 2015. Available online: https://www.bls.gov/spotlight/2015/long-termunemployment/ (accessed on 29 July 2020).

4. Kroft, K.; Lange, F.; Notowidigdo, M.J.; Katz, L.F. Long-term unemployment and the great recession: The role of composition, duration dependence, and nonparticipation. J. Labor Econ. 2016, 34, S7-S54. [CrossRef]

5. Alenda-Demoutiez, J.; Mügge, D. The lure of ill-fitting unemployment statistics: How South Africa's discouraged work seekers disappeared from the unemployment rate. New Polit. Econ. 2020, 25, 590-606. [CrossRef]

6. Blustein, D.L.; Medvide, M.B.; Wan, C.M. A critical perspective of contemporary unemployment policy and practices. J. Career Dev. 2012, 39, 341-356. [CrossRef]

7. Brandolini, A.; Cipollone, P.; Viviano, E. Does the ILO definition capture all unemployment? J. Eur. Econ. Assoc. 2006, 4, 153-179. [CrossRef]

8. Card, D. Origins of the unemployment rate: The lasting legacy of measurement without theory. Am. Econ. Rev. 2011, 101, 552-557. [CrossRef]

9. Cranford, C.J.; Vosko, L.F.; Zukewich, N. Precarious employment in the Canadian labour market: A statistical portrait. Just Labour 2003, 3, 6-22. [CrossRef]

10. Dooley, D. Unemployment, underemployment, and mental health: Conceptualizing employment status as a continuum. Am. J. Community Psychol. 2003, 32, 9-20. [CrossRef]

11. Duell, N.; Thurau, L.; Vetter, T. Long-Term Unemployment in the EU: Trends and Policies; Bertelsmann-Stiftung: Gütersloh, Germany, 2016; pp. 1-88.

12. Karjanen, D. The limits to quantitative thinking: Engaging economics on the unemployed. In Anthropologies of Unemployment; Kwon, J.B., Lane, C.M., Eds.; Cornell University Press; JSTOR: Ithaca, NY, USA, 2016; pp. 34-52.

13. Kroft, K.; Lange, F.; Notowidigdo, M.J.; Tudball, M. Long time out: Unemployment and joblessness in Canada and the United States. J. Labor Econ. 2019, 37, S355-S397. [CrossRef]

14. Kwon, J.B.; Lane, C.M. Anthropologies of Unemployment: New Perspectives on Work and Its Absence; Cornell University Press: Ithaca, NY, USA, 2016. 
15. Rothstein, D.S. Monthly Labor Review: An Analysis of Long-Term Unemployment; U.S. Bureau of Labor Statistics: Washington, DC, USA, July 2016. Available online: https://www.bls.gov/opub/mlr/2016/article/an-analysisof-long-term-unemployment.htm (accessed on 29 July 2020).

16. International Labour Office (ILO). Key Indicators of the Labour Market; ILO: Geneva, Switzerland, 2016.

17. Gilbert, K.; Tileaga, C.; Cahill, S. Dilemmas of long-term unemployment: Talking about constraint, self-determination and the future. Int. J. Educ. Psychol. Community 2014, 4, 7-33.

18. Laliberte Rudman, D. Critical discourse analysis: Adding a political dimension to inquiry. In Transactional Perspectives on Occupation; Cutchin, M.P., Dickie, V.A., Eds.; Springer: Dordrecht, The Netherlands, 2013; pp. 169-181. [CrossRef]

19. Njelesani, J.; Gibson, B.E.; Nixon, S.; Cameron, D.; Polatajko, H.J. Towards a critical occupational approach to research. Int. J. Qual. Methods 2013, 12, 207-220. [CrossRef]

20. Crenshaw, K. Demarginalizing the intersection of race and sex: A Black feminist critique of antidiscrimination doctrine, feminist theory and antiracist politics. Univ. Chic. Leg. Forum 1989, 1, 139-167.

21. Laliberte Rudman, D. Occupational terminology: Occupational possibilities. J. Occup. Sci. 2010, 17, 55-59. [CrossRef]

22. Boland, T. Seeking a role: Disciplining jobseekers as actors in the labour market. Work Empl. Soc. 2016, 30, 334-351. [CrossRef]

23. Gazso, A.; McDaniel, S.A. The risks of being a lone mother on income support in Canada and the USA. Int. J. Sociol. Soc. Policy 2010, 30, 368-386. [CrossRef]

24. Haikkola, L. Shaping activation policy at the street level: Governing inactivity in youth employment services. Acta Sociol. 2019, 62, 334-348. [CrossRef]

25. Lightman, E.; Mitchell, A.; Herd, D. Cycling off and on welfare in canada. J. Soc. Policy 2010, 39, 523-542. [CrossRef]

26. Riach, K.; Loretto, W. Identity work and the 'unemployed' worker: Age, disability and the lived experience of the older unemployed. Work Employ. Soc. 2009, 23, 102-119. [CrossRef]

27. Silver, S.; Shields, J.; Wilson, S.; Scholtz, A. The excluded, the vulnerable and the reintegrated in a neoliberal era: Qualitative dimensions of the unemployment experience. Soc. Stud. 2009, 1. [CrossRef]

28. Schram, S.F. Neoliberalizing the welfare state: Marketing policy/disciplining clients. In The SAGE Handbook of Neoliberalism; Cahill, D., Cooper, M., Konings, M., Primrose, D., Eds.; SAGE: London, UK, 2018; pp. 308-322.

29. Woolford, A.; Nelund, A. The responsibilities of the poor: Performing neoliberal citizenship within the bureaucratic field. Soc. Serv. Rev. 2013, 87, 292-318. [CrossRef]

30. Laliberte Rudman, D.; Aldrich, R. "Activated, but stuck": Applying a critical occupational lens to examine the negotiation of long-term unemployment in contemporary socio-political contexts. Societies 2016, 6, $28-45$. [CrossRef]

31. Dean, M. Governing the unemployed self in an active society. Econ. Soc. 1995, 24, 559-583. [CrossRef]

32. Rose, N.; O'Malley, P.; Valverde, M. Governmentality. Ann. Rev. Law Soc. Sci. 2006, 2, 83-104. [CrossRef]

33. Brady, M. Ethnographies of neoliberal governmentalities: From the neoliberal apparatus to neoliberalism and governmental assemblages. Foucault Stud. 2014, 11-33. [CrossRef]

34. Boland, T.; Griffin, R. The death of unemployment and the birth of job-seeking in welfare policy: Governing a liminal experience. Ir. J. Sociol. 2015, 23, 29-48. [CrossRef]

35. Laliberte Rudman, D.; Aldrich, R.M. Discerning the social in individual stories of occupation through critical narrative inquiry. J. Occup. Sci. 2017, 24, 470-481. [CrossRef]

36. Soss, J.; Fording, R.C.; Schram, S. Disciplining the Poor: Neoliberal Paternalism and the Persistent Power of Race; University of Chicago Press: Chicago, IL, USA, 2011.

37. Lipsky, M. Street-Level Bureaucracy: Dilemmas of the Individual in Public Services; Russell Sage Foundation: New York, NY, USA, 2010.

38. Aldrich, R.M.; Laliberte Rudman, D.; Dickie, V.A. Resource seeking as occupation: A critical and empirical exploration. Am. J. Occup. Ther. 2017, 71, 1-9. [CrossRef]

39. Aldrich, R.M.; Laliberte Rudman, D. Situational analysis: A visual analytic approach that unpacks the complexity of occupation. J. Occup. Sci. 2016, 23, 51-66. [CrossRef]

40. Aldrich, R.M.; Laliberte Rudman, D. Occupational therapists as street-level bureaucrats: Leveraging the political nature of everyday practice. Can. J. Occup. Ther. 2020, 87, 137-143. [CrossRef] 
41. Lassiter, L.E. The Chicago Guide to Collaborative Ethnography; University of Chicago Press: Chicago, IL, USA, 2005.

42. Scanlan, J.N.; Bundy, A.C. Development and validation of the modified occupational questionnaire. Am. J. Occup. Ther. 2011, 65, e11e19. [CrossRef]

43. Huot, S.; Laliberte Rudman, D. Extending beyond qualitative interviewing to illuminate the tacit nature of everyday occupation: Occupational mapping and participatory occupation methods. OTJR Occup. Particip. Health 2015, 35, 142-150. [CrossRef] [PubMed]

44. Laliberte Rudman, D.; Aldrich, R.M.; Grundy, J.; Stone, M.; Huot, S.; Aslam, A. “You got to make the numbers work": Negotiating managerial reforms in the provision of employment support service. Altern. Routes: J. Cri. Soc. Res. 2020, 28, 47-79.

45. Hardin, P.K. Constructing experience in individual interviews, autobiographies and on-line accounts: A poststructuralist approach. J. Adv. Nurs. 2003, 41, 536-544. [CrossRef] [PubMed]

46. Huot, S.; Aldrich, R.; Laliberte Rudman, D.; Stone, M. Picturing precarity through occupational mapping: Making the (im)mobilities of long-term unemployment visible. J. Occup. Sci. 2020, in press. [CrossRef]

47. Fanelli, C.; Laliberte Rudman, D.; Aldrich, R.M. Precarity in the nonprofit employment services sector. Can. Rev. Sociol. 2017, 54, 331-352. [CrossRef]

48. Grundy, J.; Laliberte Rudman, D. Deciphering deservedness: Canadian employment insurance reforms in historical perspective. Soc. Policy. Adm. 2018, 52, 809-825. [CrossRef]

49. Wilcock, A.A. Reflections on doing, being and becoming. Aust. Occup. Ther. J. 2002, 46, 1-11. [CrossRef]

50. Wilcock, A.A.; Hocking, C. An Occupational Perspective of Health; SLACK Incorporated: Thorofare, NJ, USA, 2015.

(C) 2020 by the authors. Licensee MDPI, Basel, Switzerland. This article is an open access article distributed under the terms and conditions of the Creative Commons Attribution (CC BY) license (http://creativecommons.org/licenses/by/4.0/). 